\title{
Gründerzeit - Od skandalu do stylu
}

\author{
Jacek K. Knothe \\ Katedra Konserwacji Zabytków, Wydziat Budownictwa i Architektury, Politechnika Lubelska, \\ e-mail:j.knothe@pollub.pl
}

Streszczenie: Przyjmuje się, iż architektura 'okresu założycieli' - 'Gründerzeit' występowała w Niemczech w latach 1870-1920, to jest dłużej niż do zakończenia I wojny światowej stanowiącej swoistą cezurę XX wieku. Na terenie Polski, w miarę rozprzestrzeniania się przychodzącego z Europy postępu technicznego, styl Gründerzeit następował pod koniec XIX wieku z niewielkim tylko opóźnieniem w stosunku do Niemiec, a wraz z nim jeszcze 12 stylów okresu historyzmu. Budynki z okresu Gründerzeit, powszechnie obecne w centrach polskich miast pomimo zniszczeń spowodowanych II wojną, stanowią zwykle obiekty najstarsze i choćby $\mathrm{z}$ tego powodu uznawane są za estetyczny kanon historycznej zabudowy mieszkaniowej. Zamiarem autora jest przywrócenie do literatury polskiej terminu Gründerzeit jako bardziej precyzyjnie określającego styl niż termin 'historyzm', używany do opisania praktycznie każdej formy architektonicznej z okresu poprzedzającego modernizm. Autorowi chodzi też o spowodowanie w polskiej literaturze dekonstrukcji terminu 'historyzm' i wyodrębnienie z niego terminu Gründerzeit, ponadto o rozprawienie się z funkcjonującymi na temat stylu Gründerzeit uprzedzeniami oraz o wykazanie związków i wpływu tego stylu na architekturę tkanki miejskiej większości polskich miast, nie tylko tych położonych na zachód od Wisły. Bezrefleksyjność lub też pogląd, iż architektura z przełomu XIX i XX wieku na terenie Polski nie miała korzeni w XIX wiecznej architekturze Europy, a jeśli nawet miała, to na pewno nie były one niemieckie, w erze globalizmu która właśnie wtedy się rozpoczynała, nie wytrzymuje próby.

Słowa kluczowe: Gründerzeit, Gründer, historyzm, eklektyzm, neostyl.

\section{Wprowadzenie}

Używany w literaturze europejskiej termin Gründerzeit, w literaturze polskiej zwykle w ogóle nie występuje w oryginale ${ }^{1}$, lecz jest tłumaczony jako 'grynderstwo' w odniesieniu do kwestii gospodarczo - politycznych, lub jako 'historyzm' w odniesieniu do architektury. Nawet jednak używając terminu Gründerzeit nie wskazujemy, czy chodzi nam o styl, okres historyczny, stosunki gospodarcze, czy charakterystykę zachowań ludzkich, i choć były one synergiczne, to jednak stanowiły kategorie odrębne.

Termin Gründerzeit w literaturze niemieckojęzycznej, lub 'Age of Promotorism' w literaturze anglojęzycznej, używany jest przede wszystkim dla określenia całej epoki w historii Prus (a później Niemiec) i Austrii od II połowy XIX wieku, zarówno w zakresie warunków polityczno - społeczno - gospodarczych, jak i panującego w tym okresie stylu architektury. Choć termin 'okres założycieli' (pol.- grynderski) istotnie łączy się z okresem wynaturzeń pierwszej fazy industrializacji, to jednak chronologicznie rzecz ujmując wyprzedza go o kilkadziesiąt lat. Ponadto, termin Gründerzeit nie stanowi w literaturze euro-

\footnotetext{
1 Encyklopedia PWN nie podaje wyników wyszukiwania znaczenia terminu Gründerzeit.
} 
pejskiej, tak jak to jest w literaturze polskiej, wyłącznie synonimu tych wynaturzeń, lecz określenie rozpoznawalnego i uznanego stylu estetycznego, nazywanego czasem „pluralizmem stylowym", panującego szczególnie w architekturze i meblarstwie ${ }^{2}$.

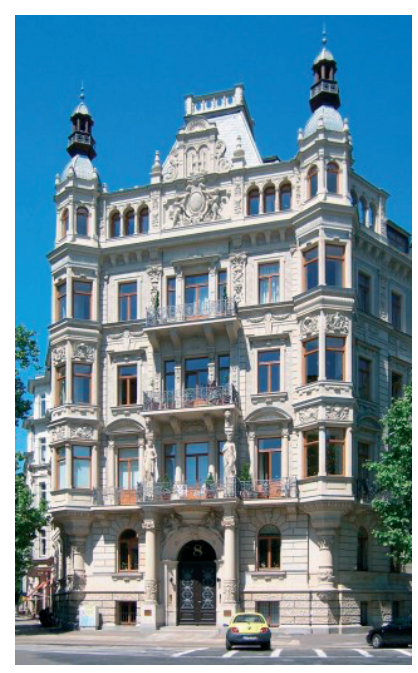

Fot. 1. Kamienica z okresu Gründerzeit w Musikviertel w Lipsku (niem. Leipzig). Beethovenstraße 8, proj. 1892, arch. Arwed Roßbach, rekontr. 2004/2005, foto: File Leipzig Palais Roßbach.jpg, Wikimedia Commons

Znamienne jest, iż w literaturze polskiej określenie 'okres założycieli' w odniesieniu do Gründerzeit stosuje się jedynie w kategoriach gospodarczych jako do prozaicznego 'zakładania' w IV kwartale XIX wieku spółek giełdowych. Terminu tego nie odnosi się natomiast zupełnie do kategorii politycznych, jako do 'zakładania' podwalin nowoczesnego na owe czasy państwa niemieckiego, jakim wkrótce, po 1871 roku, stała się II Rzesza niemiecka; co ważniejsze, nie odnosi się tego również do procesu zakładania podwalin nowoczesnej gospodarki niemieckiej.

W użyciu terminu 'okres założycieli', bo termin Gründerzeit w literaturze polskiej jest praktycznie nieużywany, zawarta jest generalnie doza amnezji zarówno co do historii Europy, jak i warunków epoki, jaką stanowiła w Europie II połowa XIX wieku. Termin Gründerzeit był dotąd w literaturze polskiej nacechowany wyłącznie negatywnymi ocenami i historyczną niechęcią do niemieckiej ekspansji gospodarczej. Zdecydowanie negatywna w polskiej literaturze konotacja terminu Gründerzeit, związana nieodłącznie z aferami finansowymi, w literaturze światowej uległa już dawno zatarciu. Samo znaczenie terminu Gründerzeit uległo złagodzeniu, przy jego równoczesnej nobilitacji z powodu łagodzących wszystko związków z kulturą masową ${ }^{3}$. Innymi słowy, określenie stylu obiektu architektury czy przedmiotu rzemiosła artystycznego mianem Gründerzeit obecnie wskazuje już zwykle tylko okres, w którym on powstał, szczególnie iż okres wpływu architektury stylu Gründerzeit szacuje się na lata 1835 - 1920, z czego okres aferalny stanowił jedynie okres zawarty

2 W kulturze niemieckiej terminy i sztuka Biedermeier i Gründerzeit są ze sobą nierozłącznie związane.

3 Dobitny tego przykład stanowi zamek w Neuschwannstein Ludwika II, ukończony w 1892 r., w ,prawdziwym stylu rycerskim”, podkreślającym romantyczny historyzm; nie poprzestano tu na wzorcach Średniowiecza, lecz połączono mauretańskie elementy z gotykiem, tworząc znany na całym świecie Bajkowy Zamek (niem. Märchenschloss"). 
pomiędzy rokiem 1871 zakończenia wojny franko-pruskiej a rokiem 1873 krachu giełdy wiedeńskiej - z pochodną 20. lecia kryzysu jako następstwa Gründerkrise.

Bariera nieznajomości języka niemieckiego, ułatwiająca swoisty kamuflaż, powodowało, że negatywne znaczenie terminu Gründerzeit w literaturze europejskiej zanikło; trudno zresztą wyobrazić sobie stosowanie z upodobaniem i bez końca określenia 'obiekt okresu aferalnego' w stosunku do wartościowych, a niekiedy również urzekających obiektów architektury wypełniających centra wielu miast europejskich.

Przyjmuje się umownie, iż architektura 'okresu założycieli' - Gründerzeit występowała w Niemczech w latach 1870-1920, to jest dłużej niż do zakończenia I wojny światowej stanowiącej swoistą cezurę XX wieku. Na terenie Polski, w miarę rozprzestrzeniania się przychodzącego z Europy postępu technicznego, styl Gründerzeit następował z niewielkim tylko opóźnieniem w stosunku do Niemiec. Kamienice z okresu Gründerzeit, powszechnie obecne w centrach polskich miast pomimo zniszczeń spowodowanych II wojną, stanowią często obiekty najstarsze i choćby z tego powodu uznawane są za estetyczny kanon historycznej zabudowy mieszkaniowej.

W literaturze polskiej dla stylu okresu Gründerzeit zarezerwowano pogardliwe miano eklektyzmu ${ }^{4}$, nie wyodrębniając go z panującego w XIX wieku w krajach Europy okresu historyzmu, obejmującego przecież kilkanaście nurtów czy neostylów. Nie pomoże tu jednak zaklinanie rzeczywistości; Gründerzeit, uparcie przez większość polskich historyków architektury tak kwalifikowany, nie był tylko przypadkowym zlepkiem stylów. Gründerzeit nie był również na terenie Polski stylem rdzennym, a nazywanie go historyzmem, choć częścią stylu i okresu historyzmu istotnie był, nie uczyni zeń stylu polskiego.

Jeżeli odnosić termin Gründerzeit do kategorii polityczno - gospodarczych, to z perspektywy czasu poprawniejsze wydaje się odniesienie do 'okresu założycieli' oraz 'ojców założycieli' nowoczesnego niemieckiego państwa - II Rzeszy, niż do epizodycznego okresu afer finansowych i nieuczciwego (grynderskiego) zysku. Jeżeli jednak odnosić termin Gründerzeit do kategorii kulturowych, jest to odniesienie do estetyki panującej w Niemczech i państwach pozostających pod wpływami niemieckimi w okresie lat 1870-1920, nie tylko w architekturze i związanych z nią zawodach artystycznych jak rzeźba, sztukateria i meblarstwo, ale i w kulturze literackiej i muzycznej; nie ma również wątpliwości, iż wpisywał się on dokładnie w formułę „narodowej świadomości - patriotycznego stylu” ówczesnych Niemiec.

Nie tracąc z oczu podłoża historycznego, w niniejszym tekście autor koncentruje się, siłą rzeczy, wyłącznie na aspektach architektonicznych i budowlanych zjawiska kulturowego, jakie Gründerzeit stanowił.

\section{Charakterystyka okresu założycielskiego Gründerzeit}

\subsection{Etymologia i znaczenie terminu Gründerzeit}

Termin Gründerzeit niesie w sobie w istocie aż cztery znaczenia i odwołuje się do różnych zjawisk, występujących w tym samym okresie, na tym samym obszarze, lecz niekoniecznie równocześnie;

${ }^{4}$ Eklektyzm [gr. eklektikós 'wybierający'], ,termin po raz pierwszy zastosowany w odniesieniu do sztuki przez J.J. Winckelmanna (1763); od tego czasu pojęcie to było różnie definiowane, (....) choć z reguły używano go w znaczeniu pejoratywnym; obecnie jest stosowane w zasadzie w 3 znaczeniach: jako określenie pewnych zjawisk fazy początkowej bądź końcowej (,schyłkowej”) niektórych nurtów stylowych (np. sztuki ptolemejskiej czy hellenistycznej), jako szeroko rozumiane określenie postawy artystycznej i jako określenie stylu w sztuce, a zwłaszcza architekturze XIX w.(...), bywa definiowany jako metoda twórcza (....) historyzmu i postmodernzmu”. - hasło „eklektyzm” Encyklopedia PWN. 
- Gründerzeit - 'grynderstwo' jako termin kolokwialny, synonim chciwości i nieuczciwości zachowań przedsiębiorców niemieckich, w okresie wczesnej industrializacji Niemiec,

- Gründerzeit - jako okres historii Niemiec w Europie, zawarty pomiędzy Märzrevolution 1848 rokiem / Wiosną Ludów, a wybuchem I wojny światowej w 1914 roku - znaczenie polityczne,

- Gründerzeit - jako okres pomiędzy 1871 r. zakończenia wojny franko-pruskiej a 1873 r. krachem giełdy wiedeńskiej - z pochodną 20. lecia Gründerkrise.

- Gründerzeit - jako oznaczenie stylu estetycznego, na terenie wpływów początkowo Prus i Monarchii Habsburgów, a następnie Niemiec i Austrii, sukcesora stylu Biedermeier i poprzednika stylu Jugendstil.

\subsection{Gründerzeit jako 'grynderstwo'}

Termin 'grynderstwo', stosując terminologię polską, jest kolokwialny i oznacza „,rozpowszechnione na przetomie XIX $i$ XX w., w okresach dobrej koniunktury gospodarczej, zjawisko zakładania spółek akcyjnych zapewniajacych wysoki zysk jej założycielom (zysk grynderski), głównie poprzez sprzedaż akcji znacznie powyżej wartości nominalnej, zawyżenie wartości kapitału założycielskiego, fatszowanie dokumentów, postugiwanie się podstawionymi osobami itp. Działalność taka, jako niezgodna z interesami akcjonariuszy, jest obecnie $w$ wielu krajach prawnie zakazana". 5

To hasło encyklopedyczne, oprócz jawnej niechęci do zjawiska spekulacji i całego zresztą systemu kapitalizmu, prezentuje stygmatyzujące półprawdy; samo 'zjawisko zakładania spółek akcyjnych zapewniajacych wysoki zysk jej założycielom' nie jest bowiem niczym nagannym, a realizowanie tego celu ,...głównie poprzez sprzedaż akcji znacznie powyżej wartości nominalnej...", jest naturalnym co do zasady atrybutem funkcjonowania giełdy, jak długo nie jest oparte o poświadczenie nieprawdy co do kondycji finansowej spółki. Inne polskie źródła ${ }^{6}$ nie są tak radykalne w ocenie tego okresu, niemniej łączą termin 'Gründerzeit' i pochodny termin 'grynderstwo' wyłącznie z nieuczciwością działań założycieli - Gründer spółek akcyjnych, ignorując uwarunkowania gospodarcze tego okresu oraz pozostałe znaczenia tego terminu.

Poglądy te należy uznać za co najmniej powierzchowne i wybiórcze, oparte o historyczne uprzedzenia, a wreszcie podświadomą i wpajaną przez lata panującego w Polsce socjalizmu niechęć do kapitalizmu jako takiego, zatem wymagające weryfikacji.

Należy przypomnieć, iż w sensie gospodarczym Gründerzeit był zaledwie kilkuletnim epizodem w historii Niemiec i Austrii, przed załamaniem się giełdy wiedeńskiej w 1873 roku $^{7}$ spowodowanym przez 'założycieli' - Gründer, jednak niejako przechodzi się nad tym do porządku, a termin Gründerzeit stosuje się jako nazwę epoki. W historii II Rzeszy widzianej oczami niemieckimi ma to wymiar porządkujący, a nie ocenny, ale nie tak chce to postrzegać

5 W literaturze polskiej [Kopaliński, W.], etymologia terminu 'Gründerzeit ', nazywanego również 'okresem grynderskim', pochodzi od słowa 'Gründer ' oznaczającego 'założyciel' od 'gründen' 'zakładać'; (u)fundować' z 'Grund 'grunt; tło; przyczyna'; Zeit 'czas'. „, W Niemczech dotyczy okresu 1871-73 po wojnie francusko-pruskiej”. Słownik wyrazów obcych i zwrotów obcojęzycznych z almanachem, Oficyna Wydawnicza RYTM, 2007.

6 Pajewski, J., Historia Powszechna 1871-1918.

7 Publiczna giełda w Wiedniu została założona na podstawie patentu udzielonego przez Marię Teresę w 1771 r. Po krachu 8 maja 1873, spowodowanego spekulacją w okresie Gründerzeit i w następstwie tego poważną recesją, w 1875 roku powołany został nadzór praktyk giełdy, lecz sama giełda zachowała niezależność.www.austria-forum.org. 
literatura polska. Jeśli uznaje się, iż w Niemczech i Austrii Gründerzeit jako styl estetyczny zaczął się, jak chcą niektórzy, około 1835 roku, równolegle z uprzemysłowieniem Wiednia, a na pewno w wyniku Märzrevolution 18 marca 1848 r., ${ }^{8}$ a liberalizm w Austrii sięgnął zenitu w 1867 roku w okresie monarchii austro-węgierskiej i dominował od 1867 roku aż do połowy lat 1870 tych, to przypisywanie w literaturze polskiej terminu Gründerzeit wyłącznie do epizodu 1871-1873 wydaje się być nieuzasadnione, a co najmniej niestosowne.

To raczej tendencja zjednoczeniowa, a potem fakt założenia państwa niemieckiego, a nie masowość czy natura afer finansowych z udziałem założycieli (Gründer)spółek akcyjnych daje asumpt do określenia okresu Gründerzeit jako 'okresu 'założycieli'. Można bowiem uznać, iż biorąc pod uwagę zróżnicowaną socjalnie i ekonomicznie sytuację krajów Europy niemieckojęzycznej, Gründerzeit postrzegany jako tendencja zjednoczeniowa Niemiec miał początek w latach 1850 tych, a więc dwie dekady wcześniej niż inkryminowane skandale.

Anglojęzyczny termin 'Age of Promotorism', stosowany wymiennie z terminem 'founding years' dla określenia Gründerzeit, zawiera wprawdzie pewien pierwiastek negatywny, chociaż 'promotor' oznacza przecież osobę stanowiącą (pozytywną) siłę sprawczą przedsięwzięcia.

\section{Europa w okresie Gründerzeit}

\subsection{Stosunki polityczne poprzedzające okres Gründerzeit}

Wyprzedzająco do zaistnienia epoki Gründerzeit, a na pewno wcześniej niż doszło do użycia po raz pierwszy tego terminu, w Europie Centralnej nadchodziła faza uprzemysłowienia, której początki można odnaleźć już w latach 1840- tych ${ }^{9}$. Początek tej fazy jest nie do ustalenia, chociaż data Rewolucji Marcowej (niem. Märzrevolution) 18 marca 1848 r. najpierw w Wiedniu, a następnie w Berlinie, dającej początek Wiośnie Ludów, jest generalnie jako ten początek uznawana. Märzrevolution domagała się wolności politycznej jednostki i równocześnie zjednoczenia państw niemieckich w jeden kraj. Wkrótce miało to się przełożyć na uznanie barw (obecnej) flagi Niemiec za narodowe, deklarację zjednoczenia Niemiec przez Zgromadzenie Narodowe we Frankfurcie i, co najbardziej istotne, na gospodarczą organizację Niemiec.

Wcześniej doszło w Wiedniu do manifestacji ulicznych, utworzono Gwardię Narodową, ogłoszono wolność prasy i zapowiedziano reformy na wsi. Wtedy też rozpoczęły się, z udziałem robotników i rzemieślników, zamieszki w Berlinie; do postulatów dołączono wolność zgromadzeń oraz amnestię dla więźniów politycznych. W wyniku wprowadzonych przez władze reform Märzrevolution zakończyła się i, chociaż reformy polityczne później cofnięto, postulowane zmiany ekonomiczne zostały zainicjowane, a uprzemysłowienie Niemiec i Austrii weszło w fazę aktywną.

Tak więc to w istocie Märzrevolution rozpoczęła Gründerzeit jako siła sprawcza.

\subsection{Stosunki polityczno-gospodarcze okresu Gründerzeit}

Utworzenie Związku Północnoniemieckiego i wygrana wojna z Francją zapewniły Prusom hegemonię w Niemczech, a proklamacja króla Prus cesarzem niemieckim w Wersalu (Versailles) 18 stycznia 1871 r. była tego ukoronowaniem. Nowe państwo przyjęło

8 Matis, H., Grundzüge der österreichischen Wirtschaftsentwicklung 1848-1914, w: Innere Staatsbildung und gesamte Modernisierung, 1991.

9 Gründerzeit und Nationsbildung1849-1871, Jansen, Ch., Schöningh UTB Verlag 2010, Seminarbuch Geschichte, Band 3253. 
nazwę Rzesza Niemiecka - das Deutsche Reich ${ }^{10}$, de facto było jednak, jak określił to sam cesarz Wilhelm I, "przedłużonymi Prusami". Taki stan zyskał zabezpieczenie prawne w konstytucji, uchwalonej 16 kwietnia 1871 r., zgodnie z którą Niemcy stanowiły federację 22 monarchii i 3 wolnych miast, to jest Hamburga, Bremy i Lubeki.

10 maja 1871 r. we Frankfurcie nad Menem ogłoszono pokój, kończący wojnę frankopruską. Francja zmuszona była oddać zwycięskim Niemcom, bo w tym czasie dokonano przecież ich zjednoczenia, Alzację i wschodnią Lotaryngię, oraz zobowiązywała się zapłacić reparację wojenną w wysokości 5 mld franków w złocie, w 0.5 mld ratach. Kontrybucja wpłynęła ożywiająco na gospodarkę niemiecką oraz pozwoliła na spłatę pożyczek wojennych i niektórych innych długów państwa niemieckiego. Najważniejsze jednak, że wyzwoliła w Niemczech industrializację i stworzyła warunki do pierwszego w takiej skali w nowożytnym świecie boomu budowlanego, jako wyniku rosnącego uprzemysłowienia.

Zasilenie każdej narodowej gospodarki taką kwotą reparacji byłoby nową jakością. Paradoksalnie, słynącą z organizacji Rzeszę doprowadziło jednak bardzo szybko, bo w dwa lata, do przegrzania gospodarki. Chociaż pierwsze sygnały nieuniknionego kryzysu zostały zignorowane przy otwarciu Wystawy Światowej w Wiedniu 1 maja 1873 r., to jednak już 9 maja (w Czarny Piątek) 1873 r., doszło do nieuniknionego załamania się giełdy w Wiedniu a następnie w Berlinie. Doprowadziło to bezpośrednio do paniki i krachu giełdy nowojorskiej we wrześniu 1873, skutkującej „Long Depression” w Stanach Zjednoczonych. Przyśpieszyło to i pogłębiło jeszcze kryzys w Rzeszy, bankrutowały liczne nowo założone firmy przemysłowe i banki, nie tylko niesolidne przedsiębiorstwa, ale i te o solidnych podstawach ${ }^{11}$. Wszystko to dostarcza powodów by uznać, że inkryminowane 'grynderstwo' nie wynikało jedynie z patologicznej nieuczciwości przedsiębiorców - założycieli (Gründer) spółek akcyjnych, ale i ze zwyczajnych zdarzeń gospodarczych.

Krach giełdy berlińskiej, który zahamował wzrost gospodarczy Rzeszy i poskutkował 20 letnim okresem stagnacji ekonomicznej, określa się w języku niemieckim jako okres Gründerkrise - 'kryzys założycieli'. Widać więc, iż wywodzenie od terminu Gründer nazw wszystkich negatywnych zdarzeń, a wreszcie terminu całej epoki wczesnego industrializmu, stanowi swoiste pielęgnowanie niemieckiej narodowej traumy.

Epoka Gründerzeit jest nieodwołalnie kojarzona z cesarzem Wilhelmem I i kanclerzem Bismarckiem. Jakkolwiek nie skończyła się wraz z nimi w 1888/1890, bo kontynuowała się w trakcie panowania cesarza Wilhelma II, to właśnie Wilhelm I i kanclerz Bismarck byli założycielami - Gründer, państwowości niemieckiej jaką znamy obecnie. Wprawdzie bowiem Rzesza wskutek Gründerkrise doznała strat, to potrafiła zahamować negatywne tendencje w gospodarce, a efektem załamania się giełdy było wprowadzenie jej nadzoru i ostateczne zachowanie jej niezależności od państwa. Okres Gründerzeit stanowił czas nie tylko powstawania i kształtowania się państwowości niemieckiej, ale i określenia zasad funkcjonowania nowoczesnej gospodarki.

\subsection{Zmiany stosunków spolecznych okresu Gründerzeit}

Na zmiany stosunków społecznych II Rzeszy okresu Gründerzeit miało wpływ zjawisko wzrostu zaludnienia; i tak w II poł. XIX w ludność świata zwiększyła się z ponad 1.1 mld do ca ponad 1.5 mld, a w 1914 r. wynosiła już 1.65 mld ludzi. W krajach rozwiniętych na zmniejszenie się śmiertelności wpłynęły postęp medycyny i rozwój oświaty;

${ }^{10}$ II Rzesza, gdyż za okres I Rzeszy uznaje się lata 962-1806.

${ }^{11}$ Maier, H., Börsenkrach und Weltausstellung in Wien, Vienna 1973; H. Matis, Österr. Wirtschaft 1848 1913, 1972. 
w latach 1871-1914 zaskakuje tempo zwiększania się liczby mieszkańców Europy Zachodniej; we Francji: z 36 do 39 mln, w Niemczech: z 40 do 67 mln, w Wielkiej Brytanii: z 32 do $45 \mathrm{mln}$ ludzi. Migrację ludności Niemiec, podobnie jak reszty Europy, powodował równoczesny rozwój przemysłu i kryzys w rolnictwie; w Niemczech zatrudnienie w rolnictwie zmalało prawie o połowę, z 64\% w 1871 r. do 39\% w 1910 r., co znalazło natychmiastowy skutek. ${ }^{12}$

Lawinowy rozwój przemysłu Niemiec spowodował tak samo lawinowy przepływ ludności rolniczej do przemysłu, równocześnie jej ilość w Niemczech zaczęła dynamicznie maleć wskutek emigracji, głównie Gdy jeszcze w 1882 roku 42,5\% ludności niemieckiej utrzymywało się z rolnictwa, w 1907 r. było to już tylko 28,6\%, co oznaczało spadek o $32.7 \%$ w ciągu 25 lat! Pod koniec XIX w. ruch emigracyjny z Europy uległ zahamowaniu, a nawet odwróceniu, gdyż przemysł niemiecki był w stanie wchłonąć nie tylko własnych, ale i obcych obywateli.

Masowa migracja ze wsi do miast Niemiec powodowała brak mieszkań, a w ciągu jednego tylko 1871 roku populacja samego Berlina powiększyła się o 133 tys. ludzi, a Lipsk (niem. Leipzig) od 1871 r. do 1914 r. zwiększył swą populację z 106 tyś. do 624 tyś. ludzi ${ }^{13}$. Musiało to w sposób nieunikniony wywołać zmianę nie tylko ilościową, ale również jakościową w zakresie budownictwa mieszkaniowego.

Trudno wyobrazić sobie spełnienie potrzeb mieszkaniowych takiej masy ludzi na drodze realizacji budownictwa mieszkaniowego metodami tradycyjnymi i to w formule jednorodzinnej. W tej sytuacji boom budowlany budownictwa wielorodzinnego, przemieszanego ze strefami przemysłowymi, w okresie Gründerzeit stał się wymuszoną koniecznością, a proces urbanizacji objął całą Europę Zachodnią i Centralną. Koniecznością stało się znalezienie nowej formuły i technologii budownictwa mieszkalnego. Tak jak neoklasycyzm realizował potrzebę stworzenia narodowej architektury monumentalnej, tak Gründerzeit, jako jedyny z pozostałych stylów historyzujących, powstały i oparty na społecznej potrzebie budowy tożsamości i kultury narodowej Niemiec stanowił zaplecze ideowe i intelektualne dla budownictwa masowego a nie monumentalnego.

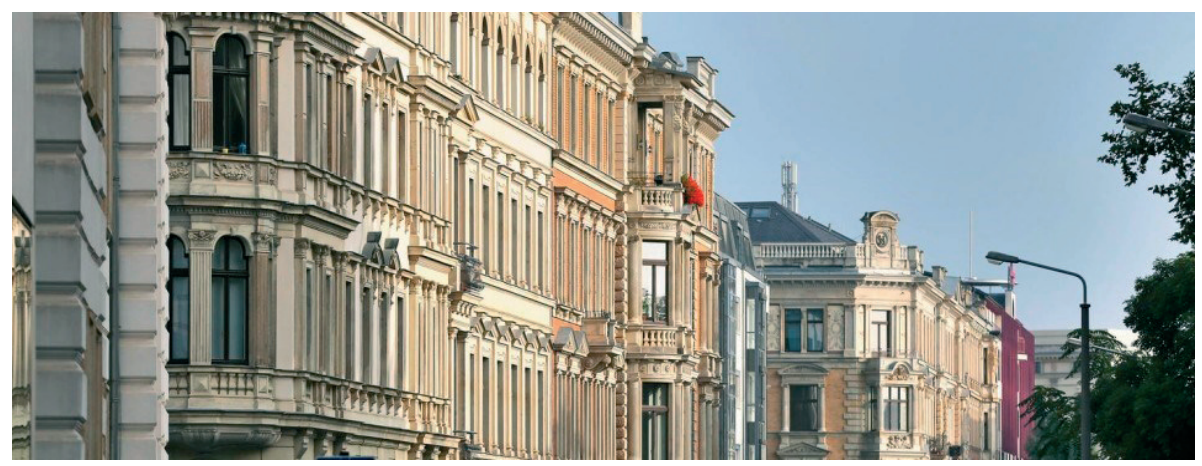

Fot. 2. Pierzeja zabudowy z okresu Gründerzeit, Lipsk (niem. Leipzig), foto: DPA

12 Analysis of regional spatial planning and decision making strategies and their impact on land use in the urban fringe Leipzig case study Sinn, A., Haase, D., Walde, A., (UFZ) str. 11.Leipzig, 2008, wg. (Nuissl \& Rink, 2005).

13 tamże. 


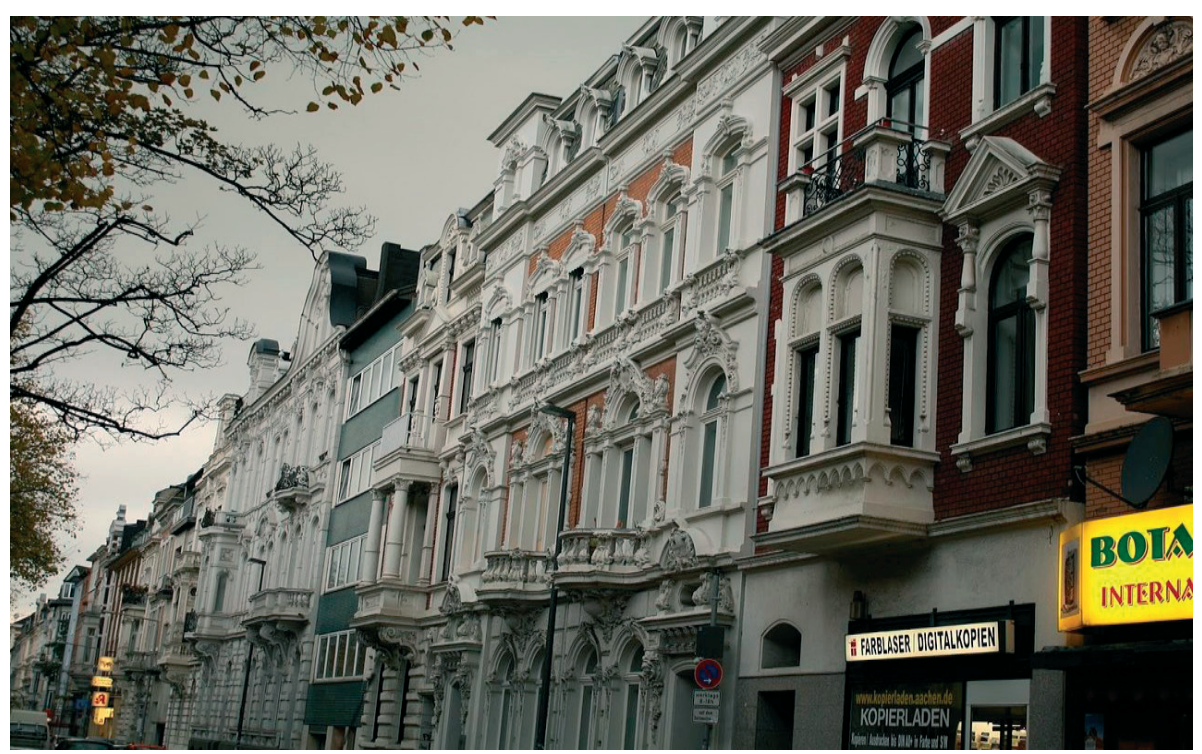

Fot. 3. Pierzeja zabudowy z okresu Gründerzeit, pocz. XX w., Aachen, foto: Sb2s3 - Own work, CC BY-SA 4.0, https://commons.wikimedia.org/w/index.php?curid=44133053DPA

\subsection{Industrializacja, wynalazki i nowe technologie}

Industrializacja Europy, szczególnie Niemiec, opierała się na wzmożonej eksploatacji węgla i rud żelaza, podstaw przemysłu okresu Gründerzeit. Miejsce warsztatów i kuźni, których produkcja oparta była o drewno i wodę, w gospodarce Westfalii, Nadrenii i Śląska zajęły huty i fabryki, lokalizowane w pobliżu występowania rud żelaza i węgla, jednak era gospodarki opartej wyłącznie na surowcach powoli jednak dobiegała końca ${ }^{14}$.

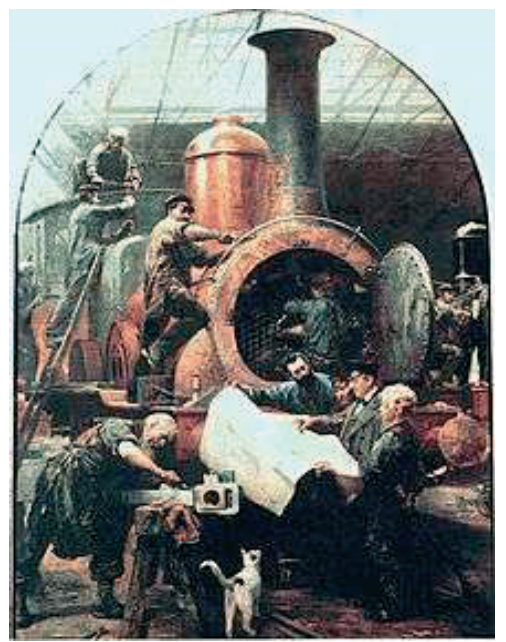

Ryc. 1. Parowóz jako siła napędowa postępu technicznego, obraz Paul Friedrich Meyerheim, 1873

${ }^{14} \mathrm{~F}$. Siemens twierdził, że to węgiel jest "miarą wszystkich rzeczy" - światowe wydobycie wzrosło z $90 \mathrm{mln}$ ton od lat 1850 -tych do $200 \mathrm{mln}$ w 1870 r. i osiągnęło $1000 \mathrm{mln}$ ton w 1913 r., szczególnie po 1892r., kiedy to rozpoczęto eksploatację rud żelaza w zagłębiu Briey w Lotaryngii (Lorraine). 


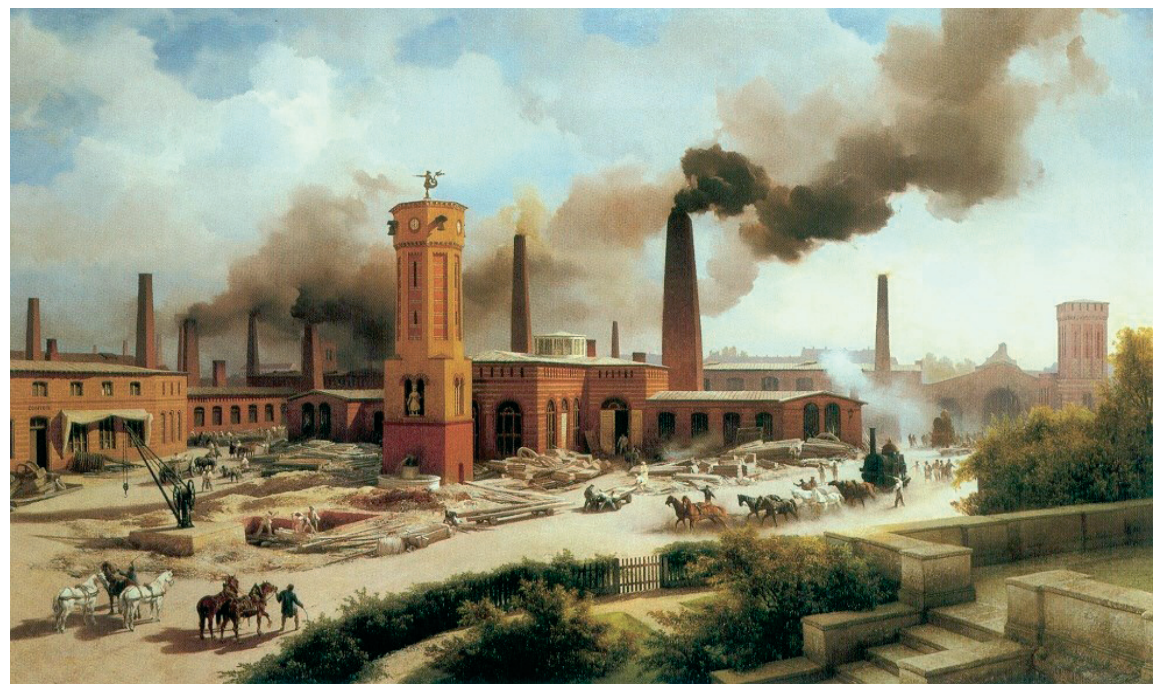

Ryc. 2. Zakłady Borsig AG w Feuerland, Berlin, mal. Karl Eduard Biermann, 1847, skan z Preußen Kunst und Architektur

Wynalazki dokonane w II połowie XIX i oparte na nich technologie, w okresie wyprzedzającym bezpośrednio Gründerzeit, miały fundamentalne znaczenie nie tylko dla procesu industrializacji Niemiec i reszty świata, ale i dla ich kultury, w tym szczególnie dla architektury Gründerzeit. Gdyby nie one, szczególnie te dotyczące użycia stali i cementu, nie mogłoby dojść do masowego budownictwa mieszkaniowego, realizowanego już jako wielokondygnacyjne, z użyciem konstrukcji stalowych, stropów typu Klein’a, a także technologii żelazobetonu.

Szczególne znaczenie zyskała stal, bo żelazo było już wcześniej, ale metody jego obróbki pozostawały nadal archaiczne, aż do wynalazku metody jego przetopu przez H. Bessemera. Wprawdzie Wojna Krymska lat 1853-1856 stanowiła idealny poligon testowania nowych technologii, ale bariera wytrzymałości żeliwnych odlewów armat przy rosnącej wadze pocisków została już przekroczona, potrzebny była wytrzymalsza i tania stal, a ta była stosowana dotąd jedynie do produkcji sztućców.

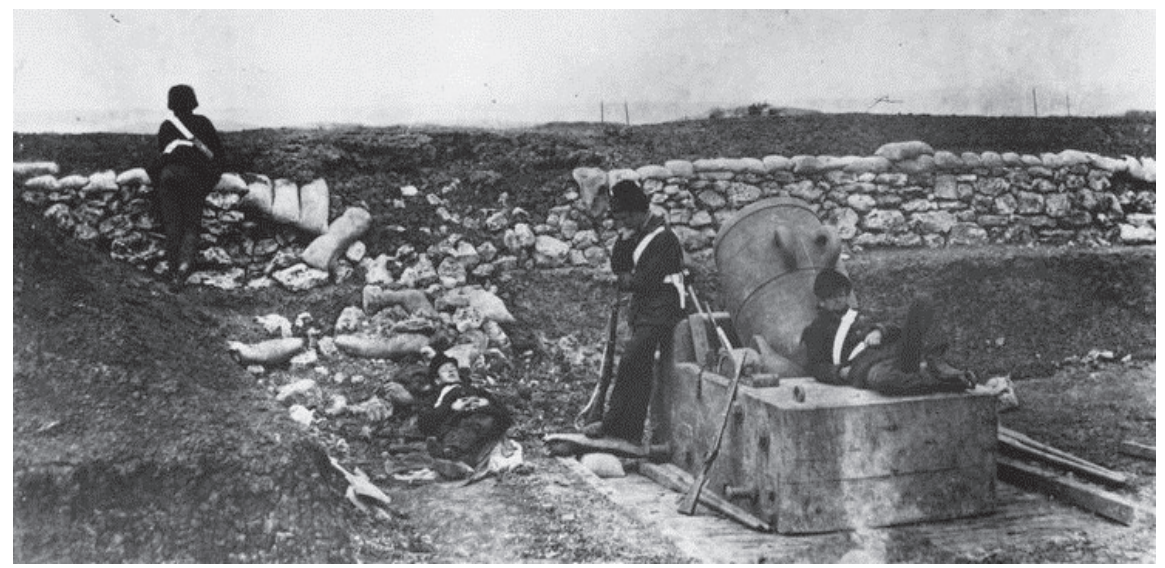

Fot. 4. Armata żeliwna używana w trakcie oblężenia Sewastopola, ok. 1855 r. fot: Roger Fenton 
W 1855 r. Bessemer opatentował przemysłowy proces masowej produkcji stali1 ${ }^{15}$, który oprócz produkcji broni umożliwiał też tanią realizację oszklonych dachów i fasad, których inspirującym pierwowzorem była konstrukcja Crystal Pallace. ${ }^{16}$ Po raz kolejny w historii potwierdziło się proste uzależnienie awangardy architektury od postępu technicznego, chociaż w procesie industrializacji Europy stanowiło to zaledwie skutek uboczny. Gdyby nie dostępność stali, nie doszłoby do jej masowego użycia w budownictwie przemysłowym w zakresie konstrukcji stalowych ze znaczącym zwiększeniem gabarytu wysokości i rozpiętości, a także w budownict2wie mieszkaniowym. Okres Gründerzeit oznacza przełomowy moment współczesnej nam już technologii budowania.

\section{Gründerzeit jako styl}

\subsection{Architektura Gründerzeit jako wynik przemian epoki}

W literaturze polskiej, termin Gründerzeit w odniesieniu do architektury thumaczony jest jako 'historyzm', a jeśli uwzględnia się tło wydarzeń gospodarczych, to w sposób mający stanowić dowód wypaczeń kapitalizmu i imperializmu niemieckiego.

W świadomości niemieckiej, Gründerzeit jest już raczej tylko nazwą okresu historycznego, z którego wywodzi się styl architektury i wzornictwa, wprawdzie przez wielu historyków sztuki i estetów lekceważony lub potępiany, niemniej odrębny i wyrazisty.

W kategoriach estetycznych, styl panujący w okresie Gründerzeit, nazywany zresztą po prostu Gründerzeit, był uznawany zaledwie za styl eklektyczny, choć dopiero od niedawna termin ten stanowi stygmatyzującą ocenę. Wbrew obiegowej opinii, eklektyczny (gr. eklektikos - wybierający) nie oznaczał jedynie mieszania niejednorodnych wzorców; eklektyzm podlegał rozwojowi i porządkował się z upływem czasu. Wrzucając go do jednego wspólnego przedziału historyzmu, należy pamiętać, iż eklektyzm był stylem odrębnym, a równolegle do niego istniało w Europie i na świecie 13 innych międzynarodowych stylów historycznych (z czego tylko trzy niereprezentowane na obszarze Niemiec), zwanych neostylami. Style te, w odróżnieniu od stylu Gründerzeit, odwoływały się do konkretnych stylów historycznych, a nawet potrafiły je twórczo reaktywować i rozwijać, niemniej Gründerzeit był konsekwentnie odrębny. W przeciwieństwie do neostylów posługujących się formami architektonicznymi bez ich związku z realiami społecznymi i gospodarczymi Niemiec, Gründerzeit był stylem głęboko w tych realiach osadzonym. Wyrósł z potrzeb i był na miarę ograniczeń i imperatywów najpierw niemieckiego społeczeństwa a później warstw mieszczańskich innych krajów, ich upodobań, gustów, a często nawet ich braku. Był populistyczny i z pewnością mniej wysublimowany i wzniosły niż neostyle historyczne, ale przez to bardziej demokratyczny. Tym styl Gründerzeit różnił się od neostylów historycznych, że jakkolwiek oparty o podobne lub te same wzorce, wzorce te przetwarzał i kompilował, a nie tylko powtarzał i odtwarzał. Różniło go od nich również to, iż będąc stosowanym przy realizacji obiektów o skali i założeniach nie monumentalnych, głównie o funkcji mieszkaniowej i przemysłowej, dawał się stosować szybko w dużej ilości wariantów.

W przeciwieństwie do neostylów występujących równolegle, styl Gründerzeit był jednak paradoksalnie stylem twórczym, a nie tak jak one, odtwórczym naśladownictwem. Z perspektywy czasu można powiedzieć, że w stylu tym projektowano celowo i rozmyślnie;

${ }^{15}$ Pierwszą firmą produkującą stal na licencji Bessemera była W \& J Galloway z Manchester, która do spółki z Bessemerem rozpoczęła produkcję stali w Sheffield w 1858 r., początkowo importując surowiec ze Szwecji.

${ }^{16}$ Crystal Pallace, autorstwa Josepha Paxtona, zrealizowana w 1851 roku na Wielką Wystawę w Londynie. 
ten styl był częścią codzienności klas średnich i wyższych, podobnie zresztą jak jego odpowiednik ideowy - styl Biedermeier.

Charakterystyka budownictwa okresu Gründerzeit z punktu widzenia współczesnego architekta jest równie fascynująca, co złożona, lecz daje się opisać w dość precyzyjnej formule; budownictwo okresu Gründerzeit w Niemczech był to stymulowany, lub nawet można powiedzieć, wymuszony industrializacją i brakiem wielorodzinnego budownictwa mieszkaniowego boom budowlany, realizowany nowoczesnymi środkami i technologiami będącymi osiągnięciami zachodzącego postępu technicznego. Było ono nieodłącznie związane z powstającym i liberalizującym się społeczeństwem, poszukującym tożsamości narodowej i kulturowej, z użyciem estetyki odwołującej się, wobec zdezaktualizowania się wzorców historycznych, do estetyki popularnej.

W zastosowaniu łącznym stylu Gründerzeit i osiągnięć technicznych tego okresu w budownictwie mieszkaniowym i przemysłowym nie ma żadnego przypadku; nie można elementów tego procesu postrzegać wyrywkowo, gdyż jest to logiczny ciąg zdarzeń natury socjalnej i gospodarczej, nie można tego również oderwać od tła jaki stanowią realia socjalne, gospodarcze i polityczne tej epoki.

Zamiarem autora jest przywrócenie do polskiej literatury przedmiotu terminu Gründerzeit jako bardziej precyzyjnie określającego styl niż termin 'historyzm', używany do opisania praktycznie każdej formy architektonicznej z okresu poprzedzającego modernizm oraz dokonanie dekonstrukcji terminu 'historyzm' i wyodrębnienie z niego terminu Gründerzeit.

Autorowi chodzi też o rozprawienie się z funkcjonującymi na temat Gründerzeit uprzedzeniami oraz o wykazanie związków i wpływu tego stylu na architekturę tkanki miejskiej większości polskich miast, nie tylko tych położonych na zachód od Wisły. Bezrefleksyjność lub też pogląd, iż architektura z przełomu XIX i XX wieku na terenie Polski nie miała korzeni w XIX wiecznej architekturze Europy, a jeśli nawet miała, to na pewno nie były one niemieckie, w erze globalizmu która właśnie wtedy się rozpoczynała, nie wytrzymuje próby.

\section{Bibliografia}

3. Andics H. Gründerzeit. Das schwarzgelbe Wien bis 1867. Jugend und Volk, Wien u.a. 1981, ISBN 3-7141-6518-5.

4. Bloch, J. Wpływ dróg żelaznych na stan ekonomiczny Rosji. w: Historia dróg żelaznych w Królestwie Polskim. Budowa i eksploatacja. t. I, Warszawa.

5. Borejsza J. Piękny wiek XIX, Czytelnik, Warszawa, 1984.

6. Cebulla F. Gründerzeit und Reichsgründung. DNB 1050939409 in: Praxis Geschichte. Westermann, Braunschweig 2014 ISSN 0933-5374.

7. Draheim K. Die Gründerzeit. auf der Website Lebendiges Museum online, LeMO, 2015.

8. $\quad$ Ernst Ch., Ernst C., Ernst E. Gründerzeit, Silberburg Verlag, 2016.

9. Haaff R: Gründerzeit. Möbel und Wohnkultur. Rhein-Verlag, Westheim 1992, ISBN 39802812-1-3.

10. Haaff R. Gründerzeit. Hartholzmöbel - Weichholzmöbel. Kunst-Verlag Haaff, Germersheim 2005, ISBN 3-938701-01-3.

11. Hamann R., Hermand J. Deutsche Kunst und Kultur von der Gründerzeit bis zum Expressionismus. Band 1: Gründerzeit. Akademie-Verlag, Berlin 1965.

12. Hilchen, H. Historia drogi żelaznej warszawsko - wiedeńskiej 1835 - 1848 - 1898. Przyczynek do historii kolejnictwa w Królestwie Polskim, Gebethner i Wolff, Warszawa - Kraków, 1912.

13. Jansen Ch. Gründerzeit und Nationsbildung 1849-1871. Verlag Ferdinand Schöningh, Paderborn, 2011, ISBN 3-506-767046. 
14. Jedlicki J. W sprawie automatycznego krachu feudalizmu. w: Między feudalizmem a kapitalizmem. Ossolineum, Wrocław - Warszawa - Kraków, 1958.

15. Matis H. Grundzüge der österreichischen Wirtschaftsentwicklung 1848-1914. w: Innere Staatsbildung und gesamte Modernisierung, 1991..

16. Meyers Großes Universallexikon, Band 6. Bibliographisches Institut, Mannheim 1982, S. 170.

17. Pajewski J. Historia Powszechna 1871-1918 - próba syntezy.

18. Roguska J. Berlińskie echa $w$ architekturze $i$ urbanistyce Warszawy $w$ XIX $i$ na poczqtku XX wieku, w: Prace Naukowe WAPW, 2002.

19. Roters E. Aspekte der Gründerzeit. Ausstellungskatalog, Akademie der Künste. Berlin 1974.

20. Sinn A., Haase D., Walde A. Analysis of regional spatial planning and decision making strategies and their impact on land use in the urban fringe Leipzig case study (UFZ) str. 11, Leipzig, 2008, wg. (Nuissl \& Rink, 2005).

21. Topolski J. Narodziny kapitalizmu w Europie. Wydawnictwo Poznańskie, Poznań, 2003.

22. Zientara B., Mączak A., Ignatowicz I., Landau Z. Dzieje gospodarcze Polski do roku 1939, Wiedza Powszechna, Warszawa, 1988.

23. Żor A. Kronenberg. Dzieje fortuny. Wydawnictwo Naukowe PWN, Warszawa, 2011.

\title{
From scandal to style
}

\author{
Jacek K. Knothe \\ Department of Conservation of Built Heritage, Faculty of Civil Engineering and Architecture, \\ Lublin University of Technology, e-mail: j.knothe@pollub.pl
}

\begin{abstract}
It is assumed, that the architecture of the 'Age of Promotorism', commonly called Gründerzeit, was omnipresent in Germany in the years 1870-1920, i.e. longer than till the end of 1st World War, being the turning point of the 20th century. In Poland, Gründerzeit style followed with only a small delay the influx and spread of technical progress and inventions from Germany. Dwellings of that time, commonly present in most Polish town centers, despite heavy demolition caused by the II World War, still constitute the oldest and most valuable part of town fabric, and are being considered the esthetic canon of historical multifamily housing relic. It is the intention of the author to deconstruct the term of 'historism' commonly used in Polish literature for practically any architectural form dating prior to modernism, isolating thereof the term of 'Gründerzeit', and to reintroduce the meaning of Gründerzeit as a more accurate term, based on historical background of 19th century Europe. It is also the aim to end the myths and the prejudice against the style of 'Gründerzeit' viewed as unwelcomed German influence. An ungrounded belief, that the XIX century architecture in Poland had no roots in 19th century German architecture, has no reason and ground in the era of globalism.
\end{abstract}

Keywords: Gründerzeit, Gründer, historism, eclectism, neostyle. 